\title{
Nutritional Studies to Evaluate the Productivity and Quality of Preserved New Variety of Hybrid Maize : 2-On Growth Performance and Economic Efficiency in Growing Kids Zaribi Goats . \\ Saleh, M. R. M.
}

Animal Production Res. Institute, Agric. Research Center, Dokki, Egypt . ABSTRACT

Use of new verity of hybrid El-Ryanah x El-Shamia maize as a new type of silage and has many attention due to their high protein efficiency, relatively high digestible energy and total digestible nutrients. Thus, the objective of this study was to evaluate feed intake, growth performance, nutrients digestibility and economic efficiency in growing kids zaribi goats. Twenty four growing zaribi kids were selected from the herd with nearly similar live body weight $13.67 \mathrm{~kg}$ and age 4 months old . Animals were divided into three groups ( $\mathrm{n}=8$ in each).All kids groups were housed in separated pens under similar environmental condition. All animals were nourished tested diet consisted of concentrate feed mixture (CFM) to cover $50 \%$ of protein requirements recommended by NRC (1989).Besides ad libitum supplement rations, where silage made of $100 \%$ berseem (BS) offered to group $1\left(\mathrm{~T}_{1}\right)$ as control silage made of $100 \%$ hybrid Raianah maize silage (HRMS) to group $2\left(\mathrm{~T}_{2}\right)$ and silage made of $50 \%$ berseem $+50 \%$ hybrid Raianah maize (HRMBS) to group $3\left(\mathrm{~T}_{3}\right)$. Feeding trails lasted for 180 days .The obtained results showed that $\mathrm{T}_{1}$ ration (100\% berseem silage) had higher NDF, ADF and ADL than those of $\mathrm{T}_{2}, \mathrm{~T}_{3}$ rations (100\% hybrid corn silage).Moreover, the supplementing of hybrid maize as silage to basal diet had contributed to a reduction giber fraction and an increase of Metabolizable energy particularly with $\mathrm{T}_{2}$ ration .Hybrid corn silage alone $\left(\left(\mathrm{T}_{2}\right)\right.$ was higher of $\mathrm{CP}, \mathrm{NFE}$ and NFC (14.89, 56.42 and 41.84 respectively), than $\mathrm{T}_{1}\left(14.67,51.63\right.$ and 41.58 respectively) and $\mathrm{T}_{3}(14.03,52.23$ and 40.60 respectively).On the other side $\mathrm{T}_{2}$ was lower of $\mathrm{CF}$, EE and Ash (17.02, 2.54 and 9.13) in comparison of $\mathrm{T}_{1}$ ( 21.45,2.94 and 9.31) and $\mathrm{T}_{3}$. ( 14.03, 2.79 and 10.17 respectively). In addition to metabolisable energy(ME) recorded the highest value with $\mathrm{T}_{3}$ ration (10.01) followed by $\mathrm{T}_{2}(9.93)$ ration and the lowest value had detected with $\mathrm{T}_{1}$ ration (9.43). Growth rate and daily body weight gain of kids fed experimental diets were recorded average daily gain values ( 146,154 and $167 \mathrm{~g} / \mathrm{h} / \mathrm{d})$ for T1, T2 and T3 respectively. Advantages percentage of total body weight of the experimental groups as found to be $3.39 \%$ and $1.27 \%$ for animal fed T2 and T3 ration compared to the control group (T1).Also, daily dry matter intake increased with T1 ration (1415) and $\mathrm{T} 3$ ration (1397) than those of the $\mathrm{T} 2$ ration $(1367 \mathrm{~g})$. Meanwhile, feed conversion was significantly among treatments (T1 , T2 and T3), being $(9.69,8.88$ and 8.37 respectively) .Moreover, TDN of T1 ration $(60.68 \%)$,T2 ( $64.65 \%)$ and T3 (63.45\%) being DCP as same trend and the values were $(9.79 \%, 10.03 \%$ and $9.56 \%)$ for $\mathrm{T} 1, \mathrm{~T} 2$ and $\mathrm{T} 3$ respectively with significant $(\mathrm{p}<0.05)$ increase for $\mathrm{T}_{2}$ ration than those of $\mathrm{T}_{1}$ and $\mathrm{T}_{3}$. The energy concentration of tested diets showed significantly among treatments $(\mathrm{P}<0.05)$ and $\mathrm{T} 3$ ration had the highest values of $\mathrm{NE}, \mathrm{ME}$, and $\mathrm{DE}$ concentration $(1.420,2.227,2.716)$ for $\mathrm{T}_{1}, \mathrm{~T}_{2}$. $\mathrm{T}_{3}$ respectively. On the other hand, growth energy (GE) value of $\mathrm{T}_{2}$ ration had decreased (1.765) than those of $\mathrm{T} 1$ ration (1.777) and $\mathrm{T} 3$ ration (1.760). Finally, economic return of kids fed $\mathrm{T} 1$ ration showed the highest average feed cost / $\mathrm{kg}$ of BWG (14.45 LE) than T2 (13.51) and T3 (12.52). Moreover, Price of body weight gain of T1 ration was higher (14.45 LE ) followed by $\mathrm{T} 2$ ( $13.51 \mathrm{LE})$ and the lowest price had recorded with T3 ration $(12.52 \mathrm{LE})$. On the other hand Improved of economic efficiency (\%) had recorded the highest value with T3 ration (12.40 LE ) while T2 ration had detected the lowest value (6.04 LE ) in comparison of control ration (T1).

Keywords: Zaribi kids,hybrid El-Raianah x El-Shamia maize,growth performance, digestion coefficient and economic efficiency

\section{INTRODUCTION}

Corn hybrids Ryanah x Shamia mixed to make silage for animals to increase the milk and performance production because it produce high yields of quality silage. A number of studies have shown that grain yield alone is the best indicator of a hybrid's performance for silage .Small ruminant production as goats and sheep are very significant component of livestock production throughout the world and more specifically in the developing countries (Thornton et al. ,2009).Thus, feeding system of ruminants specially small ruminants (goats and sheep) with conserved forages has become an important feeding strategy since they could be made available throughout the year. Nowadays, the use of corn silage as green forage in ruminant feeding has increased rapidly due to its high yielding properties, relatively high content of energy, palatability and easy incorporation in total mixed ration ( kerney et al. ,2004) . In addition to, the nutritive values of the feed would be more consistent for daily feeding. Maize as silage can be an economic source of nutrients for lactating animals ,especially on large farms where feeding can be automatically . However, hybrid corn plant silage contains high amount of starch which could possibly attribute to depression in fiber degradation some studies reported that maize plant silage can be used not only as a main source of feed for goats and cattle but also as a combination with other forages including pasture grass Doglan (2014). The amount of feed intake increased when corn silage was included in the grass silage based diets as the sole forage in sheep and goats (Charles et al. 2010). Similarly, Thiper et al. (2011) reported the inclusion of corn silage - grass silage has the potential to decrease the time required for finish goats and sheep . Meanwhile, when supplements of hybrid maize to grass on the form of silage showed decrease of organic matter (OM) digestibility overall period in dairy cattle and sheep Omar et al. (2008). found that the production of animals was increase by supplementation right amount of hybrid corn silage. Hybrid maize silage manipulation is used to improve animal growth performance as well as ruminant production. This feeding practice is showing interest in including whole corn plant silage to berseem for the ruminants particularly small ruminants like growing goats to improve the efficiency of nutrient utilization and to obtain optimum body weight. Currently a very limited number of goat farmers are feeding their animals with whole corn plant silage in Egypt. A few studies have 
evaluated the effects of the inclusion of hybrid Raianah $\mathrm{x}$ El-Shania corn plant silage to grass silage

Therefore, the objective of this study was to determine feed intake, growth performance and nutrient digestibility in goats fed different inclusions of hybrid corn plant silage to legume based diets.

\section{MATERIALS AND METHODS}

\section{Animal and housing}

The present experiment was conducted to evaluate feed intake, growth performance, nutrients digestibility and economic efficiency in growing kids zaribi goats. 24 kids aged 4 months old and average weight $13.67 \mathrm{~kg}$ were divided into three similar groups (8 animals each) according to their body weight . All kids were housed in separated pens under similar environmental condition. Animals distributed on the one of four experimental rations, the usual period for 180 days was applied. Weighing kids performed at the beginning and end of each month and once after 12 hours of deprivation of feed and water to obtain weight gain resulting in various stages of the trial course and also conducted for utilization from a new variety of hybrid corn silage.

\section{Feeding and performance}

Animal in all groups were fed a concentrate feed mixture (CFM) to cover $50 \%$ of protein requirement according to $\mathrm{NRC}(1989)$, addition to ad libitum supplement hybrid maize silage alone or with berseem mixture where $100 \%$ berseem silage( $\mathrm{BS}$ ) offered to group $_{1}\left(\mathrm{~T}_{1}\right), 100 \%$ hybrid maize silage (HMS) group $_{2}\left(\mathrm{~T}_{2}\right)$ and $50 \%$ berseem silage $+50 \%$ hybrid maize silage for group ${ }_{3}\left(\mathrm{~T}_{3}\right)$. Rations were offered twice daily at 8 a.m. and 4 p.m. while water was offered freely .

Chemical composition of feed used are presented in Table (1). Feed intake (FI), daily weight gain (DWG) and feed conversion (FC) were recorded and the live body weight (LBW) presented as average of growth performance. All diets in terms of energy and protein concentrations were similar. Dry matter intake, feed was presented 2 time daily 8 am and $4 \mathrm{pm}$. The next morning and before daily feeding, the remaining feed of the manger was daily collected and weighed to calculate DMI.During experimental period, water is available all time through the experimental period. Weighing kids biweekly with a 12 hours retrieving feed was done before every morning feeding and the results were calculated . body weight gain were determined.

Concentrate feed mixture (CFM) consisted of $25 \%$ undecortecated cottonseed meal , 38\% yellow corn, $10 \%$ soybean meal , 20\% wheat bran,3\% molasses, $2.5 \%$ limestone, $1.0 \%$ common salt and $0.5 \%$ minerals mixture.

\section{Silage preparation}

Fresh hydride maize and berseem which collected from El-Serw, Damietta's governorate after harvested was sun dried for a period of 3 days to reach a moisture content of about $65-70 \%$ and chopped (10$15 \mathrm{~cm}$ ) by a chopper machine .The silage was prepared by filling successive layers of the chopped materials and heavy trodden before adding the next layers with chopped rice straw $(4: 1)$ All silages were put in plastic bags for 8 weeks ,the color and odor were examined directly .Representative samples were taken before and after ensiling for chemical analysis .pH value and concentration acids of hybrid corn silage were recorded for whole corn samples throughout the feeding and digestibility trials. The $\mathrm{pH}$ value was measured immediately using a $\mathrm{pH}$ meter. Immediately after the measurement was competed the remaining filtrate was preserved with 2- 3 drops $5 \%$ of sulphuric acid and kept frozen at $-20 C^{\mathbf{O}}$ pending for fermentation acid analysis. Lactic acid and VFA's concentration in the silage extract were determined by using gas chromatography.

\section{Digestibility Trial}

Three growing kids from each treatment were transferred to metabolic crates with facilities to separate the collection of urine and feces to carry digestibility trials. After two weeks as preliminary period (adaptation period), the collection period for 7 days .The amounts, of feed offered were recorded, and refuse were collected, weighed and sampled daily preparing for chemical analysis. Feces were collected and recorded daily during collection period. Feces samples were prepared to chemical analysis .Finally, representative samples from faces and refusal from them were taken to analysis.

\section{Rumen liquor}

Change in the $\mathrm{pH}$ and total volatile fatty acid (TVFA's) and nitrogenous constituents of rumen liquor were studied by collecting $250 \mathrm{ml}$ of rumen liquor from each animal, using a stomach tube employing suction Lane et al.(1968). The rumen liquor was immediately brought to the laboratory and strained through four layers of cheese cloth .The $\mathrm{pH}$ was determined immediately using a digital $\mathrm{pH}$ analyzer. Soluble-N in rumen liquor was estimated by Kjeldahl's method .

\section{Hematological parameters}

Blood samples were withdrawn from the lift jugular vein of all animals before feeding. It collected into tubes with anticoagulant for determination of the total Neutrophil, Lymphocyte, Monocyte and Eosinophil on blood film stained with wrights stain according to Coles (1986).

\section{Proximate analysis and equations calculated}

Ground samples of feed offered and feces were analyzed for DM and CP percentage of corn silage and berseem according to the procedure of (AOAC ,1998), while the percentage of NDF, ADF and ADL were determined according to ( Van-Soest et al. ,1991).Digestible energy (DE, Mcal / kg DM) and ( NFC) were calculated as following :-

- Gross energy (GE, MJ $/ \mathrm{kg} \mathrm{DM})=0.0226 \mathrm{CP}+0.0407$ $\mathrm{EE}+0.0192 \mathrm{CF}+0.0177$ NFE ( Maff, 1975).

Digestible energy (DE, Mcal $/ \mathrm{kg} \mathrm{DM})=\mathrm{TDN} \%$ X0.04409 ( NRC,1995) .

- Metabolizable energy(ME,Mcal/kg DM) =0.82 XDE (Mcal/kg DM) (NRC,1995) .

- Net energy ( NE, Mcal/kg DM) 0.0.25( TDN\%) 0.12 .(NRC,1998). 
- Non-fibrous carbohydrate (NFC) OM -(CP+EE+NDF)

(Calsmigilia et al.,1995) .

Statistical Analysis

Data obtained results of experimental groups were analysed by (SAS 2009). When F test was positive least significant differences Duncan's (1955).

\section{RESULTS AND DISCUSSION}

\section{Chemical compositions}

Chemical analysis of ingredients and rations are presented in Table (1). The obtained results showed that $\mathrm{T}_{1}$ ration (100\% berseem silage) was higher of NDF ADF and ADL ADL ( 31.50 and 23.7 and 15.5 respectively) than those of $\mathrm{T}_{2} 100 \%$ hybrid corn silage ( $30.80,20.20$ and 12.50 respectively) and $\mathrm{T}_{3}$ ration ( 31.40 and 19.70 and 14.60 respectively) .

Table 1. Chemical composition, cell wall constituents and content of the feed stuffs ( on \% DM bases \%) .

\begin{tabular}{|c|c|c|c|c|c|c|c|c|}
\hline \multirow[t]{2}{*}{ Items } & \multicolumn{5}{|c|}{ Ingredients } & \multicolumn{3}{|c|}{ Experimental Rations } \\
\hline & CFM & $\mathbf{R S}$ & BS & HRSS & HRSBS & $\mathbf{T}_{1}$ & $\mathbf{T}_{2}$ & $\mathbf{T}_{3}$ \\
\hline$\overline{\mathrm{DM}}$ & 91,53 & 89.13 & 87.17 & 88.63 & 86.72 & 88.32 & 87.79 & 90.46 \\
\hline OM & 90.27 & 88.65 & 87.41 & 88.91 & 88.62 & 90.69 & 90.87 & 89.83 \\
\hline $\mathrm{CP}$ & 14.39 & 1.36 & 14.12 & 14.25 & 14.17 & 14.67 & 14.89 & 14.03 \\
\hline $\mathrm{EE}$ & 3.27 & 1.45 & 2.31 & 2.76 & 2.27 & 2.94 & 2.54 & 2.79 \\
\hline $\mathrm{CF}$ & 12.63 & 28.31 & 22.93 & 22.73 & 22.77 & 21.45 & 17.02 & 20.78 \\
\hline NFE & 59.98 & 57.53 & 48.05 & 49.17 & 49.48 & 51.63 & 56.42 & 52.23 \\
\hline Ash & 9.73 & 11.35 & 12.59 & 11.09 & 11.38 & 9.31 & 9.13 & 10.17 \\
\hline NDF & 38.57 & 39.11 & 38.73 & 40.75 & 39.53 & 31.50 & 30.80 & 31.40 \\
\hline $\mathrm{ADF}$ & 20.76 & 29.44 & 21.55 & 19.79 & 18.92 & 23.70 & 20.20 & 19.70 \\
\hline ADL & 8.34 & 9.67 & 8.39 & 7.62 & 8.85 & 15.50 & 12.50 & 14.60 \\
\hline NFC & 34.04 & 46.73 & 32.25 & 31.15 & 32.65 & 41.58 & 41.84 & 40.60 \\
\hline $\mathrm{DOM}^{* *}$ & - & - & - & - & - & 58.91 & 62.06 & 62.54 \\
\hline \multicolumn{6}{|c|}{ Metabolisable energy (MJ / kg DM) * } & 9.43 & 9.93 & 10.01 \\
\hline
\end{tabular}

*Calculated value $[\mathrm{ME}(\mathrm{MJ} / \mathrm{kg}$ DM)] = 0.16 $\times$ DOM (g digestible) : ( NRC ,1998). **DOM = Digestible organic matter

On the other hand the inclusion of hybrid corn plant silage to basal diet had contributed to a reduction in NDF, $\mathrm{ADF}$ and $\mathrm{ADL}$ and an increase of $\mathrm{ME}$ particularly with $\mathrm{T}_{2}$ ration $\mathrm{T}_{2}$ was higher of $\mathrm{CP}, \mathrm{NFE}$ and $\operatorname{NFC}\left(14.89,56.42\right.$ and 41.84 respectively), than $\mathrm{T}_{1}$ (14.67, 51.63 and 41.58 respectively) and $\mathrm{T}_{3}$

( $14.03,52.23$ and 40.60 respectively).On the other side $\mathrm{T}_{2}$ was lower of $\mathrm{CF}, \mathrm{EE}$ and Ash (17.02, 2.54 and 9.13) in comparison of $\mathrm{T}_{1}(21.45,2.94$ and 9.31) and $\mathrm{T}_{3} .(14.03,2.79$ and 10.17 respectively) .In addition to metabolisable energy(ME) recorded the highest value with $\mathrm{T}_{3}$ ration (11.77) followed by $\mathrm{T}_{2}(11.39)$ ration and the lowest value had detected with $T_{1}$ ration ( 11.26).These results are agreement with Anonymous (2005) .

\section{Growth performance and feed intake}

The growth rate of live body weight from starting of the trial (4 to 10 months) of age are shown in Table(2). Average daily gain values were 146,154 and $167 \mathrm{~g} / \mathrm{h} / \mathrm{d}$ for T1,T2 and T3 respectively. Corresponding values of total body weight gain were $26.24,27.65$ and $30.14 \mathrm{~kg}$, respectively .This results indicated that the feeding hybrid corn silage alone (T2 ration ) or with berseem in (T3 ration) had significant $(\mathrm{p}<0.05)$ higher in total body weight gain compares to control group (T1 ration). On the other hand, the obtained data showed that total dry matter intake increase with $\mathrm{T} 1$ ration (1415 g) and $\mathrm{T} 3$ ration(1397 $\mathrm{g}$ ) than those of $\mathrm{T} 2$ ration
(1367 g).Similar study to the present findings corn silage based diets is good feed intake for goat and sheep (Belewu et al.(2010) this could be due to the palatability and good fermentation characteristics of feed which attracted the goats to consume less amount of DMI particularly with T2 ration . other reason for reduction in dry matter intake (DMI) may be due back to composition of the hybrid corn silage which content the lower cell wall and high amount of carbohydrate and energy, which had increased the digestibility of the corn silage compared to berseem silage .Meanwhile, TDN and DCP \% were significantly $(\mathrm{p}<0.05)$ higher with T2 ration (64.83 and 10.03 respectively) than $\mathrm{T} 1$ ration (60.68 and 9.79 respectively) and $\mathrm{T} 3$ ration (64.54 and 9.56 respectively) In addition to, advantages percentage of total body weight of the experimental groups was found to be $3.39 \%$ and $1.27 \%$ for animal fed T2 and T3 rations respectively, in comparison with control ration (T1) . decrease of DMI of silage may be due to more rapid fermentation and physical breakdown in the rumen Dewhurst(2013).The DMI differences had been attributed to rapid rate of fermentation occurring in the rumen .

Table 2. Live body weight, body weight gain, feed intake and feed conversion of kids Zaribi goats fed tested rations.

\begin{tabular}{|c|c|c|c|}
\hline Items & T1 & T2 & T3 \\
\hline Initial BW, Kg & 13.61 & 13.97 & 13.42 \\
\hline $\mathrm{BW}^{0.75}$ & 7.09 & 7.26 & 7.01 \\
\hline Final BW ,kg & $39.85^{\mathrm{B}}$ & $41.62^{\mathrm{A}}$ & $43.56^{\mathrm{A}}$ \\
\hline Final BW 0.75 & 15.86 & 16.39 & 16.96 \\
\hline BWG ,kg & $26.24^{\mathrm{B}}$ & $27.65^{\mathrm{B}}$ & $30.14^{\mathrm{A}}$ \\
\hline Daily WG, g / h / d & $146^{\mathrm{B}}$ & $154^{\mathrm{A}}$ & $167^{\mathrm{A}}$ \\
\hline \multicolumn{4}{|l|}{ Feed intake $\mathrm{Kg}$ / day } \\
\hline Total DM intake (g / h / d) & 1415 & 1367 & 1397 \\
\hline Total DM intake / ( g / kg BW / day ) & 35.51 & 32.84 & 32.07 \\
\hline Total DM intake / ( $\mathrm{g} / \mathrm{BWG}$ ) & $53.93^{\mathrm{A}}$ & $47.71^{\mathrm{B}}$ & $46.35^{\text {B }}$ \\
\hline Total DM intake / ( $\left.\mathrm{g} / \mathrm{kg} \mathrm{BW}^{0.75}\right)$ & 89.22 & 83.41 & 82,37 \\
\hline Total CP intake $(\mathrm{g} / \mathrm{h} / \mathrm{d})$ & 207.58 & 203.55 & 196.99 \\
\hline \multicolumn{4}{|l|}{ Nutritive value $\%$} \\
\hline TDN \% & $60.68^{\mathrm{B}}$ & $64.65^{\mathrm{A}}$ & $63.45^{\mathrm{A}}$ \\
\hline DCP \% & $9.79^{\mathrm{B}}$ & $10.03^{\mathrm{A}}$ & $9.56^{\mathrm{B}}$ \\
\hline Feed conversion (feed $\mathrm{kg}$ DM / kg gain) & $9.69^{\mathrm{A}}$ & $8.88^{\mathrm{B}}$ & $8.37^{\text {B }}$ \\
\hline \multicolumn{4}{|l|}{ Feed conversion } \\
\hline TDN ( g/day ) & 860.75 & 883.77 & 886.59 \\
\hline $\operatorname{TDN}\left(\mathrm{g} / \mathrm{W}^{0.75}\right)$ & 54.27 & 53.92 & 52.26 \\
\hline $\operatorname{DCP}(\mathrm{g} / \mathrm{day})$ & 138.53 & 137.11 & 133.55 \\
\hline $\mathrm{DCP}(\mathrm{g} / \mathrm{kg}$ gain $)$ & 0.949 & 0.890 & 0.800 \\
\hline Feed advantages $\%$ & - & 3.39 & 1.27 \\
\hline
\end{tabular}

A and B Means in the same row with different superscripts differ significantly at $P<0.05$.

Wiese et al.(2003). Reported that dry matter intake may be due to a bitter availability of nutrients are readily been degraded by rumen microbes. Inclusion of corn silage to the legume silage had a positive effect on feed intake as observed by feed intake as observed by Browne (2000),reported that the DRY, dry matter intake (DMI) of kids increased within as the inclusion of corn silage with berseem in basal diet. This is due to high moisture and NDF content of the silage which physically restricts DMI. In addition to, the results Indicated that average of feed conversion ( $\mathrm{kg}$ DMI / $\mathrm{kg}$ gain) was 9.69, 8.88 and 8.37 for (T1), (T2) and (T3), respectively with significant differences among treatment. The lower feed conversion ratio was 
observed within hybrid corn silage alone (T2) or mixed with berseem (T3) .Kariuki et al. (2001) stated that cell wall content of berseem degraded slowly in the rumen and was more resistant to rumen microbial fermentation Silage quality

Results in Table (3) illustrated that, no marked differences were noticed among the three experimental treatments for $\mathrm{pH}$,while T3 appeared to somewhat higher value of lactic acid, total acidity, total acetic acid and TVFS. Meanwhile, butyric acid and ammonia of T3 ration were lower values than other tested rations. Also, results showed that the concentration of VFAS was significantly $(\mathrm{p}<0.05)$ higher with $\mathrm{T} 1$ rations $(22$ $.55)$ and $\mathrm{T} 3$ rations ( 24.71) than those of $\mathrm{T} 2$ being (19.92) . On the contrary the butyric acid \% and total acetic acid had higher with T2 than those of T1 and T3 . The data are agreement with that reported by Mostafa et al. (1999).

Table 3. Anaerobic fermentation of silage quality

\begin{tabular}{lccc}
\hline Items & T1 & T2 & T3 \\
\hline pH value & 4.21 & 4.28 & 4.36 \\
Lactic acid \% & 6.03 & 6.17 & 6.19 \\
Acetic acid \% & 2.61 & 2.29 & 2.43 \\
Butyric acid \% & 0.39 & 0.41 & 0.32 \\
Ammonia \% & 0.23 & 0.22 & 0.18 \\
Total acidity ( ml in NaOH / 100 g ) & $27.92^{\mathrm{B}}$ & $28.19^{\mathrm{B}}$ & $29.68^{\mathrm{A}}$ \\
Total butyric & 0.22 & 0.20 & 0.17 \\
Total acetic & 1.28 & 1.44 & 1.63 \\
TVFAs( ME q / 100g ) & $22.55^{\mathrm{A}}$ & $19.92^{\mathrm{B}}$ & $24.71^{\mathrm{A}}$ \\
\hline
\end{tabular}

$A$ and $B$ Means in the same row with different superscripts diffe significantly at $\mathbf{P}<0.05$.

\section{Digestibility of nutrients}

The digestibility of DM was higher for $\mathrm{T}_{3}$ ration followed by $T_{2}$ as compared to $\mathrm{T} 1$ ration Table (4) . Moreover, the digestibility of $\mathrm{CP}, \mathrm{CF}, \mathrm{EE}$ and NFE were significantly $(\mathrm{P}<0.05)$ higher with $\mathrm{T}_{3}$ ration and the lowest value had detected with $\mathrm{T}_{1}$ ration and $\mathrm{T}_{2}$ ration was moderately values .On the contrary Katole et al. (2011) observed the comparable digestibility of DM , $\mathrm{OM}$ and $\mathrm{CP}$ to control group in sheep . Generally it could be notice that $T_{3}$ showed the spurious values of digestibility of most nutrients and nutritive values .

Table 4 . Digestion coefficient and daily feed intake of differential rations

\begin{tabular}{lccc}
\hline \multicolumn{1}{c}{ of differential rations . } & T1 & T2 & T3 \\
\hline Items & & & \\
Digestion coefficient ( \%) & 1415 & 1367 & 1397 \\
DMI g / h/d & & & \\
Digestion coefficient \% & $62.93^{\mathrm{B}}$ & $65.81^{\mathrm{A}}$ & $77.33^{\mathrm{A}}$ \\
DM & $64.96^{\mathrm{B}}$ & $68.30^{\mathrm{A}}$ & $69.62^{\mathrm{A}}$ \\
OM & $66.71^{\mathrm{B}}$ & $67.38^{\mathrm{A}}$ & $68.14^{\mathrm{A}}$ \\
CP & $64.18^{\mathrm{B}}$ & $66.23^{\mathrm{A}}$ & $70.71^{\mathrm{A}}$ \\
CF & $65.19^{\mathrm{B}}$ & $69.83^{\mathrm{A}}$ & $71.11^{\mathrm{A}}$ \\
EE & $63.54^{\mathrm{B}}$ & $69.77^{\mathrm{A}}$ & $68.52^{\mathrm{A}}$ \\
NFE & & &
\end{tabular}

$A$ and $B$ Means in the same row with different superscripts differ significantly at $\mathbf{P}<0.05$.

\section{Hematological parameters}

The hematological picture of growing kids fed hybrid maize silage alone or mixture with berseem (Table 5) Showed significant $(\mathrm{p}<0.05)$ decrease in white blood cells with $\mathrm{T}_{3}(9.78)$ in comparison to $\mathrm{T}_{1}$ ration (10.64) and $T_{2}$ ration (10.11).On the other side, $T_{1}$ ration had significantly higher $(\mathrm{p}<0.05)$ in Leucocytes and Eosinophil's (17.28 and 4.36 respectively) than $\mathrm{T}_{2}$ (10.66 and 3.46 respectively) and $T_{3}$ (10.34 and 3.54 respectively). Moreover, $\mathrm{T}_{2}$ ration was higher value of Neutrophils ( 46.11) followed by $\mathrm{T}_{1}(43.59)$ and the lowest values had detected with $\mathrm{T}_{3}(39.81)$. In addition to , Lymphocytes and Monocytes were higher with T3 ( 55.19 and 17.48 respectively ) and lower values were recorded with $\mathrm{T}_{2}$ ration ( 51,70 and 12.29 respectively ), while T1 had moderate values ( 53.81 and 14.61 respectively).This is in line with Jain (1986).Generally, the obtained values are within the normal physiological ranges reported by Keneko (1989) .

Table 5. White blood cells fractionation of zaribi kids fed tested rations .

\begin{tabular}{lccc}
\hline \multirow{2}{*}{ Items } & \multicolumn{3}{c}{ Experimental groups } \\
$\mathbf{T}_{\mathbf{1}}$ & $\mathbf{T}_{\mathbf{2}}$ & $\mathbf{T}_{\mathbf{3}}$ \\
\hline $\mathrm{WBC}^{10} / \mu \mathrm{L}$ & $10.64^{\mathrm{A}}$ & $10.11^{\mathrm{A}}$ & $9.78^{\mathrm{B}}$ \\
Leucocytes $\mathrm{x}^{\mathrm{I0}} / \mu \mathrm{L}$ & $17.28^{\mathrm{A}}$ & $10.66^{\mathrm{B}}$ & $10.34^{\mathrm{B}}$ \\
Neutrophils \% & $43.59^{\mathrm{A}}$ & $46.11^{\mathrm{A}}$ & $39.81^{\mathrm{B}}$ \\
Lymphocytes \% & $53.81^{\mathrm{A}}$ & $51.70^{\mathrm{B}}$ & $55.19^{\mathrm{A}}$ \\
Monocytes \% & $14.61^{\mathrm{B}}$ & $12.29^{\mathrm{B}}$ & $17.48^{\mathrm{A}}$ \\
Eosinophil's \% & $4.36^{\mathrm{A}}$ & $3.46^{\mathrm{B}}$ & $3.54^{\mathrm{B}}$ \\
\hline
\end{tabular}

$A$ and $B$ Means in the same row with different superscripts differ significantly at $\mathbf{P}<0.05$.

\section{Rumen fermentation study}

The average value of $\mathrm{pH}$ in rumen liquor (RL) of animals in T1, T2 and T3 recorded $6.40,6.70$ and 6.50respectively,with no significant differences(Table 6) .

Table 6 . Concentration of some rumen liquor parameters .

\begin{tabular}{lccc}
\hline Items & T1 & T2 & T3 \\
\hline PH value & 6.4 & 6.7 & 6.5 \\
TVFA's (ml/100ml) & $26.95^{\mathrm{B}}$ & $29.41^{\mathrm{A}}$ & $25.72^{\mathrm{B}}$ \\
Molar proportion of individual & VFA's (\%) & & \\
Acetic Acid & $27.91^{\mathrm{A}}$ & $28.05^{\mathrm{A}}$ & $25.27^{\mathrm{B}}$ \\
Propionic acid & $15.63^{\mathrm{A}}$ & $16.53^{\mathrm{A}}$ & $13.80^{\mathrm{B}}$ \\
Buteric acid & $11.78^{\mathrm{A}}$ & $11.94^{\mathrm{A}}$ & $10.96^{\mathrm{B}}$ \\
A/P ration & $1.79^{\mathrm{B}}$ & 1.70 & $1.83^{\mathrm{A}}$ \\
Total Nitrogen $(\mathrm{mg} / 100 \mathrm{ml})$ & $124.40^{\mathrm{B}}$ & $128.17^{\mathrm{A}}$ & $131.36^{\mathrm{A}}$ \\
Ammonia nitrogen $(\mathrm{mg} / 100 \mathrm{~mL})$ & $51.76^{\mathrm{A}}$ & $48.15^{\mathrm{B}}$ & $56.62^{\mathrm{A}}$ \\
Microbial protein $(\mathrm{mg} / 100 \mathrm{~mL})$ & $52.38^{\mathrm{B}}$ & $54.86^{\mathrm{A}}$ & $55.73^{\mathrm{A}}$ \\
\hline
\end{tabular}

$A$ and $B$ Means in the same row with different superscripts differ significantly at $\mathbf{P}<0.05$.

However, concentration of TVFA's and molar proportion of propionic, acetic and butyric acid were significantly $(\mathrm{p}<0.05)$ higher with $\mathrm{T} 2$ followed by $\mathrm{T} 1$ ration, on the other side, the lower values had detected with T3 ration Offmann et al. (2003). . Meanwhile, ratio of acetic acid to propionic acid was the highest $(\mathrm{p}<0.05)$ in $\mathrm{T} 3$, moderate in $\mathrm{T} 1$ and lowest $(\mathrm{p}<0.05)$ in $\mathrm{T} 2$.The results with in agreement with those obtained by EL-Ashry et al. (1997). who reported that the minimum of $\mathrm{pH}$ ranged between ( 6.29 and 6.83). The results of TVFA's are in agreement with Richard and Allen (1997), who reported that the rumen liquor could detected differences in TVFA's concentration owing to feeds containing different levels of concentrate or soluble carbohydrate this result are agreement with Thalib and Widiawati (2009)..Concentration of ammonia nitrogen $(\mathrm{NH} 3-\mathrm{N})$, total nitrogen $(\mathrm{TN})$ and microbial protein were significantly $(\mathrm{P}<0.05)$ increased with $\mathrm{T} 3$ ration $(131.36,56.62$ and 55.73 respectively) than those of T1 (124.40,51.76 and 52.38 respectively) and $\mathrm{T} 2$ rations (128.17,48.15 and 54.86 respectively) ,which mean that the microorganisms used soluble 
carbohydrate , and NH3-N to convert it into microbial protein Wanapat (2007) .

\section{Energy concentration}

The approximately equal values of energy concentrations in diets of kids zaribi goats are shown in Table (7).Obtained data of tested diets had differences among treatments $(\mathrm{P}<0.05)$ and $\mathrm{T} 3$ ration had the highest values of NE,ME DE concentrations and the values were (1.420, 2.227 and 2.716 respectively), while GE had detected the lowest value( 1.76$)$ than others . Meanwhile the lowest values of (ME/ GE) and (NE/ME) had recorded with T2 ration (1.244 and 63.65 respectively), while the highest values were recorded with T3 ration (1.265 and 63.76 respectively), Stock et al , (2000) suggested that the improved energy responses from feeding hybrid maize silage may be due to higher fat content or potential for reducing acidosis .

Table 7. Energy concentration of kids zaribi goats fed tested rations.

\begin{tabular}{lccc}
\hline \multirow{2}{*}{ Items } & \multicolumn{3}{c}{ Experimental groups } \\
& \multicolumn{1}{c}{$\mathbf{T}_{\mathbf{1}}$} & $\mathbf{T}_{\mathbf{2}}$ & $\mathbf{T}_{\mathbf{3}}$ \\
\hline $\mathrm{NE}(\mathrm{Mcal} / \mathrm{kg})$ & Energy concentration & & \\
$\mathrm{ME}(\mathrm{Mcal} / \mathrm{kg})$ & 1.398 & 1.397 & 1.420 \\
$\mathrm{GE}$ & 2.194 & 2.195 & 2.227 \\
$\mathrm{DE}$ & 1.777 & 1.765 & 1.760 \\
$\mathrm{ME} / \mathrm{GE}$ & 2.676 & 2.677 & 2.716 \\
$\mathrm{NE} / \mathrm{ME}$ & 1.235 & 1.244 & 1.265 \\
\hline
\end{tabular}

\section{Economic efficiency}

Economic efficiency of growth performance are presented in Table(8). Data clearly that there is differences $(\mathrm{P}<0.05)$ among experimental groups. T1 ration showed the highest average feed cost / $\mathrm{kg}$ of BWG (14.45 LE) and the lowest value had detected with T1 ( 12./46) .

Table 8 . Economic efficiency (LE) of tested rations on productivity of kids zaribi goats

\begin{tabular}{|c|c|c|c|}
\hline \multirow{2}{*}{ Items } & \multicolumn{3}{|c|}{ Experimental groups } \\
\hline & T1 & $\mathbf{T 2}$ & T3 \\
\hline$\overline{\mathrm{BWG}, \mathrm{kg}}$ & 26.24 & 27.65 & 30.14 \\
\hline Daily WG, g / h / d & $146^{\mathrm{B}}$ & $154^{\mathrm{A}}$ & $167^{\mathrm{A}}$ \\
\hline Concentrate feed mixture $(\mathrm{g} / \mathrm{h} / \mathrm{d})$ & 640 & 650 & 645 \\
\hline Silage $(\mathrm{g} / \mathrm{h} / \mathrm{d})$ & 775 & 717 & 752 \\
\hline Total DM intake $(\mathrm{g} / \mathrm{h} / \mathrm{d})$ & 1415 & 1367 & 1397 \\
\hline Feed cost and economic efficiency & & & \\
\hline Cost of feed consumed (LE) & 2.11 & 2.08 & 2.08 \\
\hline Price of daily weight gain (LE) & $4.38^{\mathrm{B}}$ & $4.62^{\mathrm{B}}$ & $5.01^{\mathrm{A}}$ \\
\hline Feed cost /kg gain (LE) & $14.45^{\mathrm{A}}$ & $13.51^{\mathrm{b}}$ & $12.46^{\mathrm{B}}$ \\
\hline Revenue ( LE / h/d ) & 2.27 & 2.54 & 2.92 \\
\hline Profit $(\%)$ & $51.85^{\mathrm{B}}$ & $54.98^{\mathrm{B}}$ & $58.28^{\mathrm{A}}$ \\
\hline Improved of economic efficiency (\%) & - & 6.04 & 12.40 \\
\hline
\end{tabular}

\begin{tabular}{llll} 
Improved of economic efficiency $(\%)$ & - & 6.04 & 12.40 \\
\hline A and B Means having different superscripts within the same row
\end{tabular} are significantly different at $(\mathbf{P}<0.05)$.

- Market price of CFM $=3000 \mathrm{LE} /$ ton , price of live weight gain $=30 \mathrm{LE} / \mathrm{kg}$. - Price of hybrid corn $=180 \mathrm{LE} / \mathrm{ton}$,

- Price of Egyptian berseem silage $=240 \mathrm{LE} /$ ton Price of Egyptian berseem $x$ hybrid corn silage $=210 \mathrm{LE}$

Moreover, Price of daily weight gain of $\mathrm{T} 3$ ration was significantly $(\mathrm{p}<0.05)$ higher $(5.01 \mathrm{LE})$ followed by T2 ( $4.62 \mathrm{LE})$ and the lowest price had recorded with $\mathrm{T} 1$ ration $(4.38 \mathrm{LE})$. However, the kids fed T2 and T3 ration showed that the lowest feed cost ( 2.08 and $2.08 \mathrm{LE}$ ) and the highest price of $\mathrm{kg}$ gain( 4.62 and 5.01 respectively .Profit (\%) had recorded with $\mathrm{T} 3$ ration $(58.28 \%$ ), in comparison of $\mathrm{T} 2$ ration ( $54.98 \%)$, On the other hand and the lowest value had detected with $\mathrm{T} 1$ ration $(51.85 \mathrm{LE})$. On the other hand , improved of economic efficiency was higher with T3 and $\mathrm{T} 2$ rations ( 12.40 and 6.04 respectively ).

These results may be due to saving higher amount of high expensive feed mixture and also replacing high expensive berseem hay by cheaper silages (Murdoch,1962).

\section{CONCLUSIONS}

Diet based on $50 \%$ hybrid corn silage and $50 \%$ berseem or $100 \%$ hybrid corn silage achieved a greater growth performance when compared with those of berseem silage alone. Therefore, in terms of growth performance maize is preferable to berseem as a starch source for meat ruminants. In practice the result of the present study showed that inclusion of a new hybrid corn silage to the basal diet had resulted in linear improve in feed intake, BW gain and feed conversion ratio. The highest efficiency of these parameters was observed in kids fed with T2 diet, also goats fed the mixture diet is likely to be influenced by the relative cost of the three starch sources .Finally, From the results of this study could be concluded that feeding ration contained hybrid corn silage to zaribi kids improved growth performance, feed conversion and decreased feed cost of producing one $\mathrm{Kg}$ gain (by 12. 95 and $5.23 \%$ ) compared to kids fed $\mathrm{T} 1$ ration .

\section{REFERENCES}

AOAC. (1998). Official Methods of Analysis. Association of Official Analytical Chemists, 14th Edition, Washington DC, pp. 141.

Anonymous (2005). Annual Progress Report of Animal Research Department, First Research councilAnimal Production Subcommittee Meeting, April, 8-9, 2005.

Belewu MA, Belewu KY and Ogunsola FO (2010). Nutritive value of dietary fungiTreated silage and the growth and digestibility coefficient of goat. Agriculture and Biology Journal of North America, 1: 135-138.

Browne, E.M. 2000. Maize silage- based diets for finishing beef cattle. Ph.D. Thesis. The University of Reading, UK.

Calsmigilia , S.; Stem M .D. andFirnkine J.L. ( 1995 ) . Effect of protein source on nitrogen metabolism in continuous culture and intestinal digestion in vitro .J. Anim. Sci.73: 1819.

Charles ,V.G. D., Pereira, O.G., Valadares Filho, S.D.C., Ribeiro, K.G., Pereira, D.H., Cecon, P.R. and Silva, B.C.D.(2010). Effect of replacing Tifton 85 hay withcorn silage on intake, digestibility, and performance of crossbred Limousin x Zebu bulls. Rev. Brasil de Zootec., 35(5): 2172-2178.

Coles , E.H.( 1986 ). Vetrinary Clinical Pathology . W.B.Saunders Company, Philadeliphia . USA.

Doglan ,T. M.E. (2014).performance of goats fed diets containing different levels of energy. South African Journal of Animal Science .30(1): 77-81.

Duncan, D.B.(1955). Maltiple range and multiple F-test . Biometrics, 11: 1- 42 .

Dewhurst,R.J.(2013).Milk production from silage: comparison of grass, legume and maize silages and their mixtures, J.Sci.Food Agri.22: 57-69. 
El-Ashty , M.A.; M.F. Ahmed ; S.A.El-Saadany ; M.E.S.Youssef ; I.A.Gommaa And T.A.A.Deraz (1997).Effect of mechanical or mecanobiochemical treatments of crop residues on there use in ruminal rations, digestibility, nitrogen balance and some rumen liquor parameters of sheep . Egyptian J. Nutrition and feeds . 1:173186

Jain, N.C. (1986). Veterinary Hematology. $4^{\text {th }}$ Ed., Lea \& Febiger. Pheladelphia

Thiper et al., D.T., Browne, E.M., Fisher, A.V., Bryant, M.J., Nute, G.R. and Beever, D.E. (2011). Intake, growth and meat quality of steers given diets based on varying proportions of maize silage and grass silage. J. Anim. Sci. 81(01): 159-170.

Kariuki, J.N.,Tamminga, S., Byachuiri, C.K. Gitau,G.K.and Muia, J.M.K.( 2001). Intake and rumen degradation in goats fed berseem (Trifollium alexandrinum) with hybrid cotn silage . S. Afr. J. Anim. Sci. 31(3):149 -157.

Katole S, Saha SK, Sastry VRB, Lade MH and Prakash $B$ (2011). Intake, blood metabolites and hormonal profile in sheep fed processed . Animal Feed Science and Technology, 170: 21-26.

Keneko. I.H. (1989). Chemical Biochemistry of Animals. $4^{\text {th }}$ ED. Academic Press, Inc

Kerney, D.J.R., Cherney, J.H. and Cox, W.J. (2004). Fermentation characteristics of corn forage ensiled in mini-silos. J. Dairy Sci. 87: 4238-4246.

Offmann P.J., Heinrichs, A.J. and Lehman, H.A. (2003). The effect of corn silage particle size on eating behavior,chewing activities and rumen fermentation in lactating cows, J. Dairy Sci. 86: 3343-3353.

Lane GT, Noller CH, Clendrander VP, Cummings KR and Harzington, R.B. $1968 . \quad$ Apparatus for obtaining rumino-reticular samples and the effect of sampling location on $\mathrm{pH}$ and volatile fatty acids. Journal of Dairy , 51: 114-123.

Maff, ( 1975). Ministry of agriculture dirts . J. Anim. Sci. $87 \mathrm{v}(9): 2906-2912$.

Murdoch,J.(1962). Making and feeding silage.Farming Prees Book,LTD , London.

Mostafa , M.R.R.; M.F.El-Sayes ; M.K.Hhathout and K.E.I.Etmsan ( 1999) .

Nutritional studied on conserved peanut tops as silage andhay using sheep Egyptian J.Nutrition and feed 2 ( Special ISSUE) : 253-263.
NRC( National Research Council, (1985). Nutrient requirement of sheep ( $6^{\text {th }}$ Rev. Ed . National academy press , Washington, DC.

NRC(1989) .National Research Council Nutrient requirement of dairy cows. Sixth revised edition. National Academy of Science, Washington, DC.

Offmann P.J., Heinrichs, A.J. and Lehman, H.A. (2003). The effect of corn silage particle size on eating behavior,chewing activities and rumen fermentation in lactating cows, J. Dairy Sci. 86: 3343-3353

Omar, F.P. , gerald J.J. and Murphy, W.R.(2008).The effect on milk production of replacing grass silage with maize silage in the diet of dairy cows. Livest. Prod. Sci. 55: 79- 87.

Richard, Luther and Allen, Trenkle (1997), Ruminal acid production in lamb fed pelleted diets containing different level of concentrate .J.Anim.Sci.26:590-594

SAS. (2009). SAS/STAT® 9.2 User's Guide, 2nd ed. SAS Institute Inc, Cary, NC USA

Stock , R. R.A., J.M.Liwes, T.J.Kloipfenstein , and C.T.Milton ( 2000). Review of new Information on the use of wet and dry milling feed by products in feedlot diets. J.Ani,. Sci. Available : Symposia / proceding / 0924 . pdf .Accessed : Jan. 14, 2006

Van Soest, P.V., Robertson, J.B. and Lewis, B.A. (1991). Methods for dietary fiber, neutral detergent fiber, and non-starch polysaccharides in relation to animal nutrition. J. Dairy Sci. (10): 3583-3597.

Wanapat ,M.A. 2007).Manipopulation of rumen fermentation with organic supplementation in ruminants raised in the Pakistan, J. of Nutrition , 6(1) 20-27

Thalib, Y. and, A. Widiawati (2009). Comparison of fermentation kinetics (in vitro) of grass and shrub legume leaves: The pattern of VFA concentration . Indo. J. Agri. 2(1): 21-27.

Wiese, S.C., White, C.L., Masters,D.G., Milton, J.T.B.and Davidson, R.H. (2003). Growth and carcass characteristics of prime lambs fed diets containing urea, lupins or canola meal as a crude protein source. Aust. J. Exp. Agr. 43(10): 11931197.

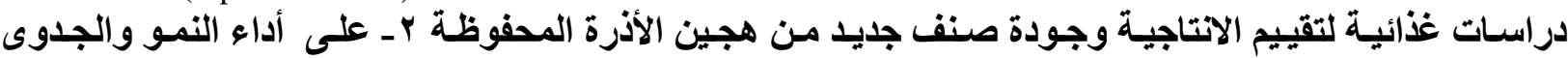
الإقتصادية فى الجديان الزرايبى النامية مصطفى راشد محمد صالح

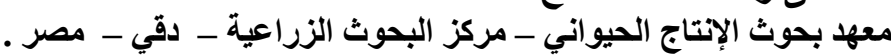

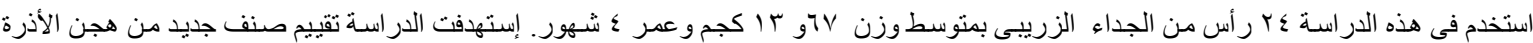

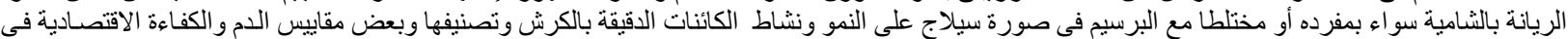

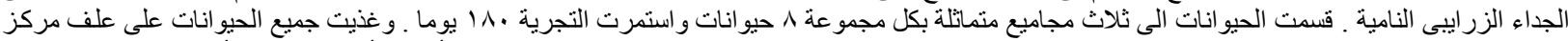

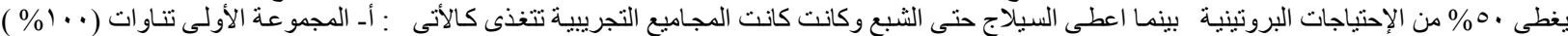

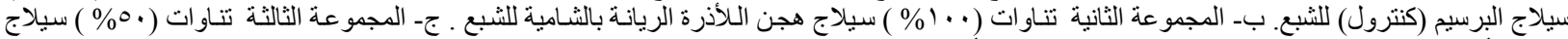

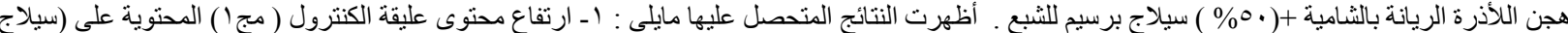

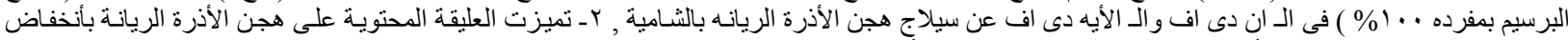

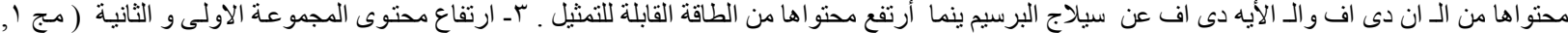

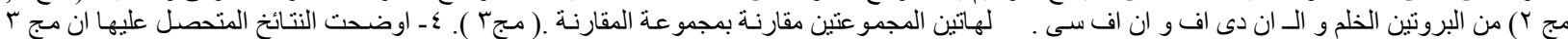

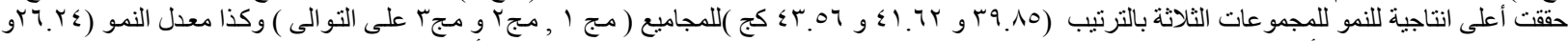

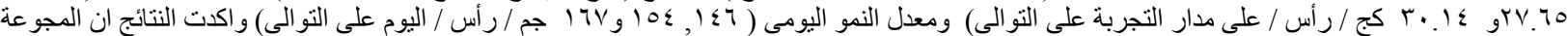

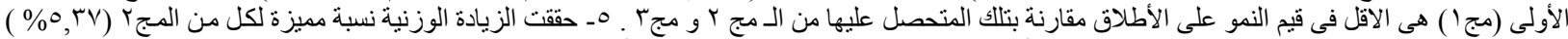

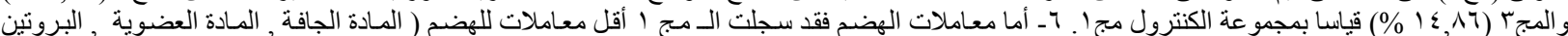

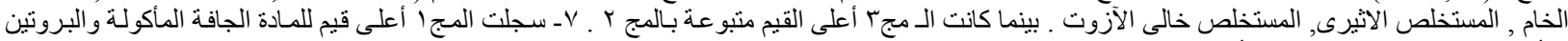

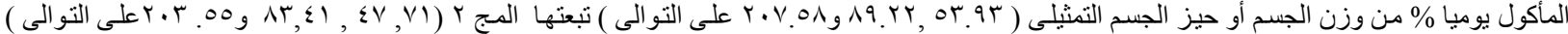

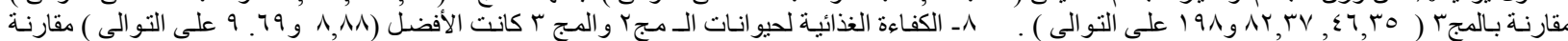

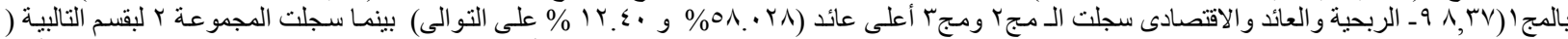

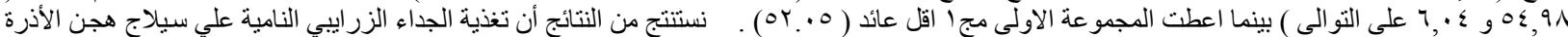

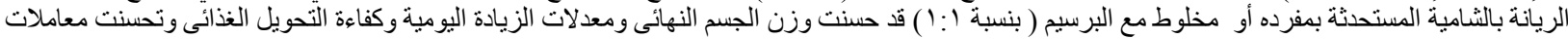
الهضد وكذا تحسنت بيئة الكرش و الطاقة الكلية و الكفاءة الأقتصادية الرئة
} 